\title{
Secondary Vocational Schools Influence Factors Analysis of Accounting Major Students' Ideological Education Work
}

\author{
Xia Xiu-fang \\ Wu Tan \\ Hebei College of Industry and Technology, \\ Shijiazhuang,050000, Ch ina
}

\author{
Liu Xuan-yu \\ School of Economics \& Management, \\ Beijing Forestry University \\ Beijing,100083 China
}

\begin{abstract}
Secondary vocational schools accounting major students' ideological education work to improve comprehensive management level of accounting major students' ideological and moral accomplishment and schools is of great significance. In this paper, with a secondary vocational school accounting major students in Shijiazhuang city, Hebei province, on the basis of the survey data using SPSS13.0 statistical analysis software and construction of multivariate regression model, analysis the influence factors of secondary vocational school accounting major students ideological education work. Results show that the secondary vocational school accounting major students' ideological education work with the students' grade, the school's emphasis on strengthening students' ideological education are negatively related degree, and students to the one-child, monthly spending has a positive correlation. This paper family will continue to adhere to implement the policy of "one-child policy"; Schools should strengthen and emphasize the senior student ideological education work; Guide the students to set up the correct monetary view; To students' thought education situation in the nation, to understand the actual circumstances of the students' ideological education, to carry out the work of students'ideological education targeted suggestions.
\end{abstract}

Keywords-secondary vocational school; accounting major students; ideological education; influence factors; multivariate regression;

\section{INTRODUCTION}

At present, the domestic research for students' ideological education work influence factors are less, and it mainly adopts qualitative method. Liu Xiaoxia and $\mathrm{He}$ Yujie(2005) think that because of network information impact and market econo my negative influence, traditional education restriction, students' bad behavior habits and psychological problem cut and weakening, making university ideological education work effect face serious challenges.[1]Xing Yongsheng (2012)put forward the education role of ideological and political course, focusing on campus culture construction, strengthening ideological political education suggestions. [2] Yang Changjiang (2003)put forward the suggestions of quickly improving teachers' ideological political quality and business level and creating the social environment of benefiting students' healthy growth and noticing parents' example role. [3] From the whole, using the quantitative methods for ideological education of students in Secondary Vocational accounting factors research are less.

This paper takes the students of Hebei industrial vocational technical college vocational accounting major(original Hebei banking college accounting major students)investigation data as the basis, using SPSS13.0 statistics software to construct multiple regression model, analyzing the influence factor of vocational accounting major students' ideological education work, in order to fully play the students' ideological education work leverage effect, improving the overall ideological moral level of vocational accounting students and university's comprehensive management ability.

\section{DATA SOURCE AND SAMPLE FEATURE DESCRIPTION}

\section{(1) Data Source}

Hebei Industrial Vocational Technical College "vocational college accounting specialty occupation education project in 2013 for Hebei Industrial Vocational Technical College vocational accounting major (original Hebei banking school accounting major)second and third year students conduct sampling investigation, altogether with 156 pieces of questionnaires to students and recovered questionnaires of 142 pieces, with effective questionnaires of 135 pieces. Through the questionnaire, it conducts investigation of vocational accounting major students' individual situation, school and class ideological education situation and students' daily life situation, laying a foundation for the data in this paper.

In order to ensure the validity of questionnaires, the author uses SPSS13.0 statistics software to make reliability analys is of recovered 135 pieces of effective questionnaires, and the result is as follows.

Reliability Statistics

\begin{tabular}{|r|r|}
\hline $\begin{array}{c}\text { Cronbach's } \\
\text { Alpha }\end{array}$ & N of Items \\
\hline .724 & 9 \\
\hline
\end{tabular}

The result shows that Cronbach's Alpha coefficient is 0.724 , showing that the questionnaire data has a good validity.

\section{(2) Sample Feature Description} 1)Students'Individual Basic Situation

In this research, men and women were respectively $16 \%$ and $84 \%$, which is closely related to the ratio of male and female students in accounting major of vocational school. In the surveyed students, the family occupies $15 \%$ of the 
province capital city and above accounted for $15 \%$, the prefecture level city, county-level city, the county accounted for $3 \%$, the county city and county accounted for $44 \%$ and the rural accounted for $38 \%$. A mong them, the only children account for $23 \%$, and the grade is concentrated in the second year and the third year, monthly expenses (not including tuition, accommodation)500-800 yuan account for $42 \%$, 500 yuan below, 800-1000 yuan account for $23 \%$, and $1000-1500$ yuan account for $11 \%$.

\section{2)School and Class Ideological Education Situation}

The investigation result shows that $59 \%$ of students think that school students' ideological education work is not in place, and counselor(head teacher) and class student party member, student cadres for students' ideological education work role is not obvious. Although most students think that school focus on students' ideological education work, but the effect is not obvious.

\section{3)Students' Daily Life Situation}

This investigation is mainly for students' daily life and online situation. The investigation result shows that $64 \%$ of students are online more than 2 hours every day. Among them, some students have online time of more than 6 hours every day. $58 \%$ of students online are to listen to music to release pressure or chat with classmates or friends, and the student online playing games are $27 \%$.

\section{INDEX SELECTION AND MODEL ESTABLIS HMENT}

\section{(1) Index Selection}

In selecting index, it follows scientific, systematic, operation, representative and unique principle, trying to truly reflect the status of the ideological education students of accounting specialty in secondary vocational schools. At the same time, in order to maintain the validity of the data, this study established 8 indexes according to the above principles.

It makes the relevant analysis of the selected 8 indexes and school students' ideological education work situation, and the obtained results are as shown in Table 1.

Tab. 1 Correlation analysis of indicators and students' ideological education work

\begin{tabular}{ccc}
\hline & & $\begin{array}{c}\text { School ideological } \\
\text { eduction work is good or } \\
\text { not }\end{array}$ \\
\hline Pearson Corelation & Whether school ideological & 1.000 \\
& education work is good or not & \\
& Gender & 0.532 \\
& Family place & -0.707 \\
& Only children or not & 0.658 \\
& Grade & -0.799 \\
& Monthly fee (yuan) & -0.705 \\
& School for strengthening & -0.748 \\
& students' 'ideological & \\
& education focus degree & \\
& Teachers' education situation & -0.688 \\
& for students & \\
Online time every day & -0.762 \\
\hline
\end{tabular}

From the table, the various index obtained relevant coefficient absolute value were more than 0.5 , belonging to moderate correlation. Accordingly, this study identified more than 8 indexes.

\section{(2) Model Establishment and Variable Definitions}

This study is explained variable is vocational accounting major students' ideological education work effect situation, using SPSS13.0 statistics software to construct multiple regression model. The model is as follows.

$$
Y=\beta_{0}+\beta_{1} x_{1}+\beta_{2} x_{2}+\cdots+\beta_{i} x_{i}
$$

Among them, $\mathrm{Y}$ is whether secondary accounting ideological education students, $\beta_{0}$ is constant, and $x_{i}$ is explanatory variable. $\beta_{i}$ is the regression coefficient of each explanatory variable.

To be specific, $\mathrm{x}_{\mathrm{i}}$ represents influencing vocational accounting students' ideological education work, including,

$\left(\mathrm{x}_{1}\right)$, family place $\left(\mathrm{x}_{2}\right)$, whether only children or not $\left(x_{3}\right)$, grade $\left(x_{4}\right)$ and monthly expenses(yuan) $\left(x_{5}\right)$, school for strengthening ideological education focus degree $\left(\mathrm{x}_{6}\right)$, teachers' ideological education situation for students $\left(x_{7}\right)$, online time every day $\left(x_{8}\right)$.The variable definition explanation is as shown in Table 2.

Tab. 2 Variable definitions and settings

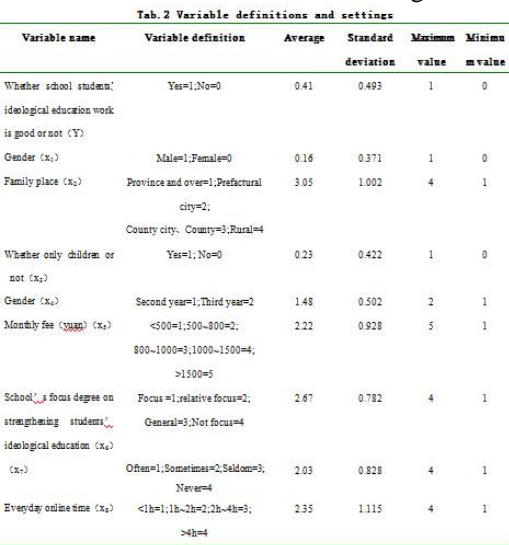

\section{RESULT AND ANALYSIS}

It adopts multiple regression model regression result is as shown in Table 3 , and the model $\mathrm{R}^{2}$ value is 0.761 , showing the model overall goodness is higher.

Tab.3 secondary vocational scool accounting students' ideological education work factors affecting multiple regression results (a)

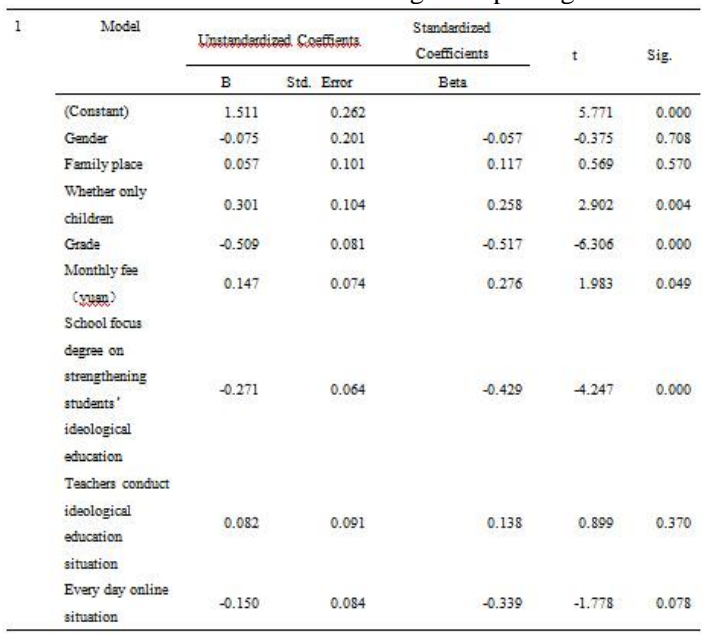


a Dependent Variable:school ideological education work is good or not.

For the regression result, it makes detailed analysis as follows.

First, students' individual basic situation. The model evaluation result shows, student gender and family place coefficient have not passed testing, showing 2 factors are not significant for vocational accounting students' ideological education work influence, and whether only children and monthly fee for vocational accounting students' ideological education work has important positive role, showing only children's ideological education situation are better than non-only children, and monthly fee (below 1500 yuan), it is good for students' ideological education work, and in the grade, it has reverse role for vocational accounting students' ideological education work, showing the higher grade is, and the investigation subject's ideological education level is lower.

Secondly, the school and class ideological education situation. The school strengthens the students' ideological education focus degree for the reverse role of accounting students, namely, school focus degree higher is not good for ideological education work, which shows that the school strengthens students' ideological education and doesn't truly understand students' ideological education status.

Finally, students' daily life situation. In the investigation, it finds that most students online are for relaxing and reducing pressure, so it has small influence on students' overall ideological education work.

According to the above model, it obtains the regression equation:

$Y=1.511+0.301 x_{3}-0.509 x_{4}+0.147 x_{5}-0.271 x_{6}$

From the regression equation, we can see that, the research object's ideological education work and the grade relationship are close. Relatively speaking, it has small relationship with monthly fee.

\section{CONCLUSION AND ADVICE}

This paper uses multiple regression model to study vocational accounting students' ideological education work influence factor. The research result shows that, vocational accounting students' ideological education work and students' gender and family place are not related, and it has no clear relation with students' ideological education situation and students' every day online time. And it has negative correlation with grade, school for strengthening students' ideological education work focus degree, and it has positive correlation with students' only children, monthly fee and it has close relationship with students' grade.

According to model estimation result, the author puts forward the following suggestions.

(1)We should continue to implement national "family planning" policy and conforming families are at most with two offsprings.

The survey finds that, the only children's ideological education situation is better than non-only children, and the reas on may be that only children get education, and obtain the care are better than non-only children, especially multiple children, which will influence the ideological moral level of children in the family.

\section{(2)Schools should know clearly about students' ideological situation and targetedly have ideological education work.}

From the new students, the school should have a census of students' ideological situation, know clearly about students' thinking. According to students' features and demand, they should stick to theory and practice, advancing with the times, adopting lively and vivid, flexible and scientific and effective method, conducting students' ideological education work.

(3)School should establish and perfect ideological education work mechanism and making ideological education work into students' process at school.

The school should establish and perfect ideological education work mechanism, making ideological education work into students' life and study process. While doing students' school education, they should focus and strengthen higher grade of students' ideological education work, making higher grade students keep a good ideological moral situation, making it have a leading role for junior students and doing the mentoring work.

\section{(4)Guiding students to establish correct concept of money.}

The school should positively guide students to establish correct concept of money, and they should not blindly compete the psychology, making students have correct outlook on life and values.

Finally, the school should strengthen the counselor's team construction, increase the education supervision strength for students and timely understand students' ideological situation, leading students to correctly use network and fully play the leading role of student cadre and student party member, making students upright. The school, family and society should combine together to form resultant force, thus, it can truly cultivate higher ideological level and modern vocational education talent of students. [4]

\section{ACKNOWLEDGMENT}

Project name: Hebei Province education science " $12^{\text {th }}$ five year" plan topic: vocational college accounting education teaching research(topic number: 13051453)

\section{REFERENCES}

[1] Liu Xiaoxia, He Yujie. Analysis on college students' ideological education work challenges[J]. Heilongjiang Higher Education Research, 2005(7): 132-133.

[2] Xing Yongsheng. Analysis on cultivation method of higher vocational students' ideological education[J].Science Education Forum, 2012(4):158-159. 